\section{Hans Schoots \\ Hollandse Documentaire School...}

(Reactie van de auteur op de boekbespreking in TMG I3/2OIO-I)

Met veel plezier las ik in TMG I3/20IO-I de mooie dingen die Thunnis van Oort schrijft over mijn proefschrift Bert Haanstra - Filmer van Nederland. Ik heb weinig klachten. Bovendien is het in Nederland toch al niet gebruikelijk dat je als auteur in discussie gaat met een recensent. In de Angelsaksische landen gebeurt het vaker, waaruit, vind ik, blijkt dat ze de wetenschap daar ernstiger nemen dan bij ons.

Bij één passage uit de recensie maak ik dus toch maar een kanttekening. Van Oort schrijft:

'Schoots verzet zich verder tegen het begrip "Hollandse documentaireschool" zoals dat werd gehanteerd in Bert Hogenkamps geschiedenis van De (Nederlandse) documentaire film (2003). Deze school heeft nooit bestaan, en dit begrip is door tijdgenoten ook nauwelijks gebruikt, aldus Schoots. Hogenkamp geeft in zijn studie echter ronduit toe dat deze zogenaamde "school" vooral een door de buitenwereld toegekende, generaliserende kwalificatie was, dus deze kritiek lijkt wat gezocht.'

Hier geeft de bespreker de inhoud van mijn boek niet juist weer. Ik verzet mij tegen het begrip Hollandse Documentaire School zoals dit gedurende vijftig jaar door vrijwel iedereen is gehanteerd. In mijn boek noem ik in dit verband een hele reeks namen, inclusief die van mijzelf. Zie ook de noten.

Het gewraakte begrip is vooral leven ingeblazen door de filmgeneratie van de jaren zestig. Deze gooide er in één zwaai bijna twee decennia Nederlandse documentaireproductie van haar voorgangers mee op een hoop. Vervolgens is deze visie een idée reçue geworden dat tot op de dag van vandaag voortleeft. Vooral het latere gebruik van het begrip Hollandse Documentaire School wekt ten onrechte de schijn van distantie en diepere beschouwing.

'Hollandse Documentaire School' is een van de belangrijkste kernbegrippen uit de Nederlandse filmgeschiedschrijving. In mijn boek heb ik het onbruikbaar en een filmhistorische mythe genoemd, en daar een reeks argumenten bij gegeven. Hier volgt daarvan een zeer summiere samenvatting.

De school zou hebben bestaan van kort na de Tweede Wereldoorlog tot ergens in de eerste helft van de jaren zestig. De navolgende kenmerken worden er gewoonlijk aan toegeschreven:

- filmkunst ten koste van de inhoud;

- weinig maatschappelijke betrokkenheid;

- geen oog voor individuele mensen;

- een eenzijdig visuele benadering met gebruik van voice over in plaats van levend geluid;

- 'typisch Nederlandse' onderwerpen als water, wind en wolken, scheepvaart en visserij.

Uit de genoemde periode zijn alweer even geleden ongeveer vijfhonderd Nederlandse documentaires geteld. Een nieuwe telling zou er nu waarschijnlijk nog een paar honderd extra opleveren. Enkele tientallen titels uit deze massa - altijd dezelfde - worden nu al een halve eeuw voorgesteld als representatief voor een tijdperk. Dat zijn ze niet. In de meeste films van toen staat de inhoud voorop. Ze hebben met hun veelal concrete informatieoverdracht een directe maatschappelijke functie en relevantie. En natuurlijk gaan talloze ervan ook 
niet over water, wolken en schepen. De voice over wordt inderdaad veelvuldig gebruikt, hoewel lang niet altijd. Met een Hollandse school heeft dit weinig te maken. Het gebeurde overal op de wereld, onder meer door technische beperkingen ten aanzien van live geluidsopnamen. Individuen konden hierdoor ook lastig hun diepste zielenroerselen uiten. Een op veel plaatsen in de wereld en ook in Nederland geregeld gebruikte vorm ter vervanging van de voice over was geluid dat wel live leek, maar in de studio tot stand kwam. Ook al niet de beste manier om 'echte' individuen te krijgen.

Vergelijking van Nederlandse met buitenlandse documentaires uit die tijd laat al met al grote overeenkomsten zien. Mede door de geluidsbeperkingen is er, ook in informatiefilms, vaak een zekere nadruk op het visuele. Een mooie illustratie hierbij zijn de verwantschappen tussen Spaanse, Franse, Belgische en Nederlandse landbouwfilms, voornamelijk uit I950-I965, op de dvd-set Film and the modernisation of agriculture and countryside (2009), een samenwerkingsproject vanuit een aantal Europese ministeries van landbouw.

Bert Haanstra geldt als voorman van de Hollandse Documentaire School. In mijn boek concludeer ik dat een groot deel van zijn films niet voldoet aan de kenmerken die daaraan worden toegeschreven. Zijn werk in de 'school' onderbrengen staat een reële kijk erop in de weg. Hetzelfde geldt voor de toenmalige Nederlandse documentaireproductie als geheel. Anders dan in het concept 'Hollandse Documentaire School' wordt verondersteld, was het belangrijkste aspect aan de documentaireproductie uit die periode haar - vaak zeer concrete - maatschappelijke functie. Daar doen wat vormexperimenten weinig aan af. Het zou goed zijn verder onderzoek vooral te richten op twee kwesties. Op de inhoud en de maatschappelijke boodschap van deze meestal informatieve, voorlichtende en propagandistische films. En op hun enorme verspreiding en de uitwerking die ze hadden op een breed publiek in die (bijna) televisieloze tijd. Incidenteel is er al zulk onderzoek gedaan. Wanneer het meer systematisch gebeurt, zal denk ik eens te meer worden vastgesteld dat het begrip Hollandse Documentaire School niet tot inzicht bijdraagt.

Naschrift Thunnis van Oort: In de geciteerde passage uit de recensie heb ik alleen willen benadrukken dat het begrip 'Hollandse documentaireschool' door Hogenkamp al kritisch werd gebruikt; Hogenkamps kanttekeningen worden door Schoots ook 'terecht relativerend' genoemd (p. I8I). Als recensent viel het mij op dat deze relativering in dezelfde alinea nagenoeg wordt tenietgedaan. Het is niet aan mij om Hogenkamps gebruik van de term toe te lichten of te verdedigen, daarvoor kunnen Schoots en Hogenkamp zich beter tot elkaar wenden - dat zou in mijn ogen ook een gerichter debat opleveren. Het Tijdschrift voor Mediageschiedenis zou daar natuurlijk graag een platform voor bieden. 